\title{
What a Meta Analytic Review of Three Decades of SSR Says about Reading Comprehension
}

\begin{abstract}
The purposes of this meta-analytic study were to imestigate the overall effect of Sustained Silent Reading (SSR) on reading comprehension and to identify the moderator variables of SSR on it. As a research method for this study, a meta-analytical approach developed by Hedges and Olkin (1985) was used. Resulis indicated that the average of effect size on reading comprehension is. 11. Lor moderator variables, only grade level was found to be significant for reading comprehension. 'These findings suggest that providing a fixed period of time for students 10 rend malerials of their own choosing either for plensure or for informalion may not sufficiently facilitate their reading comprehension. To foster children's reading comprehension through the SSR activity, therefore, it should be combined with a variely of literacy activities such as writing. discussion, and talking that increase participation and interaction with their peers and teachers. Nlso, this study supports the recommendation of earlier intevention of SSR in improving students' reading comprohension.
\end{abstract}

Key Words : Stuntined Silent Reading (SSD, Reading Athitude, Meta Analysis

\section{I . Introduction}

In an effort to achieve higher level of reading competency, which might be tequisite for building a thoroughly democratic and affluent society, most education systems worldwide have emphasized independent reading and voluntary reading as important educational objectives (Elley, 1994). Also, the majority of teacher educators and teachers in the field of reading education have rated highly the instructional goal of fostcring students' rcading attitude (Morrow, 1991). Nevertheless, alitcracy, "lack 
of the reading habit in capable readers," (Harris \& Hodges, 1995, p. 6) has been serious concerns for children in societies of many countries. According to the recent OECD/PISA (Programme for International Student Assessment 2001), only ten percent of 15-ycar-olds worldwide can read sophisticated texts, evaluate the information and apply it to everyday experiences. Further, most of them do not read for enjoyment. Of those who read, most do for less than an hour per day out of school (Henry, 2001).

As a way of achicving high level of reading competency through cultivating a love of reading, Sustained Silent Reading (SSR) has gained popularity in many elementary and secondary classtooms in the United States, Canada, United Kingdom, and New Zealand (Dymock, 200; Nagy, Campenni, \& Shaw, 2000). Reviews of SSR (e.g., Dymock, 2000; National Reading Panel, 2000, Krashen, 2001), however, failed to establish its consistent impact on reading comprehension. For example, the meta-analytic report by the National Reading Panel (NRP) questioned whether SSR has a positive influence on reading comprehension (NRP, 2000). In contrast, charging that the NRP report omitted a large number of relevant studies and misinterpreted some studies, Krashen (2001) argued

At worst, the impact of free reading appears to be the same as that of traditional instruction, and it is often better, especially when studies are continued for more than an academic year, a finding that the National Reading Panel has obscured by omitting innportant studies and by describing others incorrectly (p. 122).

Indeed, scientific evidence regarding the effectiveness of SSR on reading comprehension is equivocal. The NRP report failed to find a convincing explanation of the noneffetiveness of SSR on reading comprehension. Similarly, Krashen (2001) failed to provide empirical evidence regarding whether having children read freely for information or for pleasure affected their reading comprchension. To help fill this gap, therefore, additional rescarch required.

It was the purpose of this paper to examine the effects of SSR on reading comprehension by employing Hedges and Olkin's (1985) meta-analytic procedure. Two research questions were posed: (a) Does SSR enhance students' reading comprehension and (b) what contextual features of SSR are associated with students'reading comprehension? The purpose of the first question was to evaluate the overall effect of SSR on reading comprehension. The second question permitted the identification of SSR moderator variables on it. 


\section{II . Theoretical Framework}

\section{SSR and Reading Comprehension}

Frequent exposure to printed materials is probably a major source of a reader's vocabulary knowledge and background knowledge growth. Many rescarehers have woll documented the relationship between knowledge of word meanings and backgtound knowledge and reading comprehension (e.g., Anderson \& Freebody, 1981; Bransford \& Johnson, 1972). The important conclusion drawn from this relationship is that more vocabulary knowledge or more prior knowledge facilitates better comprchension.

With respect to the growth of such knowledge, many researchers have suggested the importance of frequent print exposure. Several studies of the relationship between comprehension and print exposure have supported that frequent exposure to print fosters reading comprehension (e.g., Anderson, Wilson, \& Fielding, 1988; Cipielewski \& Stanovich, 1992). For example, Cipielewski and Stanovich (1992) reported that children with high levels of print exposure are more likely to be better reader than children with low levels of print exposure. This finding yields an affirmative answer to the idea that readers get richer as a result of frequent exposure to print, whereas readers get poorer as a result of infrequent exposure to print (Stanovich, 1986).

In this regard, cultivating a love of reading may be one of the most important school-related tasks to increase children's exposure to print and then to foster their literacy develoment. As a reading activity to cultivate a love of reading as well as to achieve high level of reading, in particular, SSR has been implemented in many elementary and secondary classrooms for the last three decades. It has been argued that there are three important characteristics of SSR, which are supposed to mediate the relationship between reading attitude/reading comprehension and the activity. In other words, these characteristics influence attitude toward reading, which in tum increases exposure to print out of school. Finally, frequent exposure to print enhances reading comprehension. These include self-selection, role modeling, and non-accountability. 


\section{A. Self-Selection}

Readers may pay closer attention, persist in their reading for longer periods of time, learn more, and enjoy their involvement to a greater degree when they read materials that interest them. According to Deci and Ryan's (1985) theory of self-determination and intrinsic motivation, children's natural curiosity energizes their desire to learn. The self-determination theory suggests that children are motivated when they have choice and ownetship in what they read. Therefore, providing children with an opportunity to select reading materials promotes their literacy development because they have their own ownership of what they read (Shannon, 1995).

Several studies have demonstrated that individual preference of topics has a facilitative effect on cognitive and affective functioning. For example, Rehder (1980) sought to determine "how much liking affects reading achievement." Secondary school students involved in a popular fiction course who allowed to choose paperback books significantly outperformed control group students who participated in a composition class. Similarly, Cecil's (1984) reported that Native American students who read books in which they were interested demonstrated higher reading attitude and reading comprehension of those books compared to books in which they were less interested. More recently, Schiefele (1991) investigated how college students'interest in materials influenced their comprehension when their prior knowledge of the materials and general intelligence were controlled. Sehicfele found that students who were interested in the matcrials processed those matcrials more deeply than did students less interested in the materials. Furthermore, Fink (1996) showed that even dyslexics, who were hampered by persistent deficiencies in basic reading skills, could construct meaning in a single high interest domain. In contrast, when self-choice is removed, individual intrinsic motivation to reading may be diminished (Gottfied, 1990). These results suggest that preference might be a crucial motivational element leading to an increase of reading attitude and reading comprehension. Thus, by providing opportunities for self-selection in SSR, a teacher can foster children's involvement in reading materials and promote their literacy development.

\section{B. Role Modeling}

Human behavior is learned in part by observation and imitation (Bandura, 1986). For young children, in particular, a given behavior modeled by parents, teachers, peers, or celcbritics may facilitate their learning of it. From this lens, showing a reading behavior to them may be one of the most important sources of developing their attitude toward reading. Several researchers in the field of 
literacy education have suggested that role modeling is a crucial factor for reading attitude acquisition and development. For example, Gambrell (1981) stated that "students need to see that we value reading and that reading is important in our lives. Share with your students. What better way to show them that reading is important?" (p. 898). Wheldall and Entwhistle (1988) conducted a study to determine whether teacher tole modeling is an important factor in children's reading behavior development. Fourth-grade students of mixed ability participated in SSR activity over a six-week pcriod. They reported an overall mean increasc in on-task-reading behavior of $32 \%$ from initial baseline to second intervention when a teacher modeled reading during SSR sessions. These results clearly demonstrate that a teacher role modeling as nonverbal feedback plays a crucial role in fostering children's reading attitude.

\section{Non-accountability}

Children may not be required to keep records, prepare book reports or daily reading journals, or write summarics during SSR sessions. In high accountability, it may lead cven active readers to invent ways of showing the autonomy of their reading for the teacher, while for reluctant readers it may be so threatening that they never experience the pleasure of reading. In this regard, one teacher who participated in the Nagy et al.'s survey (2000) strongly commented that "reading should be a spark to ignite a fireheavy accountability tends to throw water on the spark. If it is graded, it defeats the purpose of reading class . . . to become life-long readers" (p. 6). Schiavone's (2000) study also showed that accountability for reading did not play a crucial tole on the reading comprehension and attitude of seventh-grade children. Thus, instead of imposing heavy-accountability, rather teachers should always exert all possible efforts to share his or her reading experience with children and to entice comments from them about reading out of the activity.

\section{Variability in Study Features}

Studies included in this analysis differ in methodological and procedural features as well as sample characteristics such as the type of treatment conducted, participant characteristics, sample size, and type of control group used. Such contextual features known as moderator variables (Rosenthal, 1984) may be associated with variations in the magnitude of the relationships between an independent variable and a dependent one. That is, some contextual characteristics across the reviewed studies may influcnee significant variability in the magnitude of the relationships, that is, in the effect sizes of those studies. From the literature review, several contextual features (e.g., publication type, 
duration of treatment, treatment type of control group, participant's grade level and ability level, methodological quality, and teacher's role) were found as potential moderator variables of SSR studics. Of them, two contextual factors, duration of treatment, and participant's grade level, were analyzed because they are more significant moderators that exert on influence on the effect sizes of the studies as compared with the other ones.

\section{A. Duration of Treatment}

Each of studies included in this analysis varies on its duration of treatment. Intervention of several studies (Dully, 1989; Schon, Hopkins, \& Vojir, 1985) lasted more than a semester, approximately 6 months, while that of others (Box, 1984; Collins, 1980) did less than 6 months. However, evidence regarding the effectiveness of duration of treatment as a moderator variable on reading comprehension is equivocal. Even one school-year study (Dully, 1989) did not report a positive effect on reading comprehension, whereas a 6-week study (Burley, 1980) showed a positive effect on it. In light of the cost and the effort of producing a given effect, duration of treatment gives us indicator to evaluate practical value of the progtam. For instance, if shott duration of treatment can produce a significant impact on reading comprehension as much as longer duration of intervention, less expensive and effortful one may justify broad dissemination ad adoption. In this regard, I chose duration of treatment as a moderator variable to investigate if such contextual factor influenees significant variability in the magnitude of the effect sizes of those studies. The level of this moderator was classified as more than 6 months and less than 6 months because a semester-treatment-duration, approximately 6 months or less, is not substantially short in school context.

\section{B. Grade Level}

A variety of grade levels of students ranging from a second grader to a college level have participated in SSR. However, empirical support regarding the effectiveness of grade level on reading comprehension is equivocal. Burley (1980) reported that thete is a statistically significant effect for the sixth through eighth-grade students, whereas no significant one is found for the fifth through seventh-grade students (Summer \& McClelland, 1982). Box (1984) showed that there is not a positive effect for the third graders, while a significant difference is found for the third graders (Recdy, 1994). In view of the effectiveness of intervention, it is important to know at which grade levels such contextual factor influences the magnitude of a relationship because it may provide us an 
optimal time to maximize the effectiveness of SSR intervention. In this regard, grade level of students was selected as a moderator variable to investigate if such contextual factor moderates significant variability in the magnitude of the effect sizes of those studies. The grade level was classified as below 3rd grade and above 4th grade because after the third grade children are likely to participate in leisure options such as sports and social communities, which can influence the magnitude of the effectiveness of SSR intervention.

\section{III . Method}

\section{Data Collection}

To evaluate the effectiveness of SSR on reading comprehension, the investigator employed a meta-analytical approach developed by Hedges and Olkin (Hedges \& Olkin, 1985). To identify relevant studies, ERIC (Educational Resources Information Center) and UMI (University Microfilms) databases were searched. In particular, including unpublished doctoral dissertations as well as unpublished articles in this analysis helps me avoid more or less publication bias related to the "file drawer problem" (Rosenthal, 1979), which is tendency for authors not to submit and journals editors not to accept for publication studies that fail to produce statistically significant results. However, the search was limited to the research and literature from 1970 to the present because research on SSR has been widely conducted since Hunt (1970) introduced Uninterrupted Sustained Silent Reading (USSR) as one of the important elements of an Individualized Reading Program (IRP).

Through such search, over 70 studies were collected as a preliminary data set. At the initial selection, abstracts of over 70 studies were reviewed and 25 studies remained. For the review of the second list, full texts of 25 studies were reviewed based on the following criteria: (a) an SSR group was compared to a control group, (b) studies contained enough statistical information to estimate effect size, (c) studies were published or unpublished after 1970, and (d) outcome measures included reading comprehension.

To exclude the results from poorly designed studies that failed to control threats to internal validity, additionally, judgmental review with the help from a graduate assistant was included in this second review. This has been done by judging studies as good or bad, and comparing the results (scoring agreement of .90). Then, a couple of studies (i.e., Zephaniah, 1988; Burley, 1980) lacking 
internal validity were excluded from this meta-analysis. After the second reviewing, 10 studies remained in the analysis.

\section{Effect Size Calculation}

The meta-analysis program developed by Schwarzer (1996) was used to calculate effect sizes. Effect size (ES) is calculated by the following function in the program: $\mathrm{ES}=(\mathrm{Xe}-\mathrm{Xc}) /$ SDpooled, where Xe is mean of experimental group, Xc is mean of control group, and SDpooled is pooled standard deviation of the groups.

For studies including multiple treatments case, the effect size of each comparison was calculated individually. For studies in which multiple outcome measures were used, the effect size of each dependent measure was averaged. Thus, 10 studies for reading comprehension were selected and 11 effect sizes were calculated.

In addition to the calculation of effect sizes, statistical analyses of the effect sizes were performed. For the first purpose of this study, the null hypothesis that the population value of weighted average of corrected effect sizes equals zero was tested. To identify the moderator variables of SSR, a Qstatistic (Hedges \& Olkin, 1985) that assesses if the effects produced by a group of studies vary primarily because of sampling error or represent systematic differences among the studies, was used.

\section{IV . Results}

\section{Overall Effect}

Eleven comparisons from 10 studies were used to get the average effect size of SSR on reading comprehension. The mean of effect size (ES) was .11, and its standard error was .04. The statistical test did not support the hypothesis that the population ES is zero $(\mathrm{X} 2(1)=8.29, \mathrm{p}<.05)$. The result indicates that there is statistical support for SSR affecting students' reading comprehension. Table 1 shows the descriptive statistics on the effect size of reading comprehension. 
What a Meta Analytic Review of Three Decades of SSR Says about Reading Comprehension

〈Table 1) Descriptive Statistics on the Effect Size of Reading Comprehension

\begin{tabular}{c|c|c|c|c}
\hline Dependent Variable & $\begin{array}{c}\text { Number of Studies } \\
(\mathrm{N}=\text { Sample Size })\end{array}$ & Effect Size & $\begin{array}{c}\text { Standard } \\
\text { Error }\end{array}$ & $95 \% \mathrm{CI}$ \\
\hline Comprehension & $10(3022)$ & $.11 *$ & .04 & $.02, .17$ \\
\hline
\end{tabular}

\section{Moderator Variable Effect}

The table 2 displays descriptive statistics for the effect size by duration of treatment and grade level. The $\mathrm{Hb}$ statistic, the test of heterogeneity, indicated that effect sizes are not different by duration of treatment $(\mathrm{X} 2(1)=.051, \mathrm{p}>.05)$. This result shows that there is no effect size difference between more-than 6-month duration of treatment and less-than-6-month one. That is, SSR equally fosters students' reading comprehension regardless of duration of treatment.

〈Table 2〉 Descriptive Statistics on the Effect Size of the Moderator on Reading Com

\begin{tabular}{c|c|c|c|c|c}
\hline Moderator & Level & $\begin{array}{c}\text { Number of Studies } \\
(\mathrm{N}=\text { Sample Size })\end{array}$ & Effect Size & $\begin{array}{c}\text { Standard } \\
\text { Error }\end{array}$ & $95 \% \mathrm{CI}$ \\
\hline \multirow{2}{*}{ Duration } & $<6$ Months & $6(1870)$ & .10 & .05 & $.01, .19$ \\
& $\geqq 6$ Months & $4(1215)$ & .09 & .09 & $-.03, .20$ \\
\hline \multirow{2}{*}{ Grade* } & $\leqq$ 3rd Grade & $2(324)$ & .20 & .11 & $-.03, .42$ \\
& $>$ 3rd Grade & $5(1902)$ & .16 & .04 & $.07, .25$ \\
\hline
\end{tabular}

In contrast, the $\mathrm{Hb}$ statistic for grade levels showed that effect sizes differed on students' grade levels $(\mathrm{X} 2(1)=4.77, \mathrm{p}<.05)$, indicating that SSR is a more effective reading activity to increase reading comprehension for the lower grade students than for the high grader students.

\section{Discussion and Implications}

One of the most important findings of this study was an affirmative evidence for the failure of educationally significant reading comprehension gains from a fixed period of time for students to read materials of their own choosing either for pleasure or for information. As outlined above, the average effect size of SSR on reading comprehension was .11, which corresponds to the 54 th 
percentile, indicating that the reading comprehension score of the average individual in the SSR group exceeds the scores of $54 \%$ of individuals in the control group. Although the result indicates that there is statistical support for SSR affecting students' reading comprehension, it may not educationally support the effectiveness of the SSR reading activity at enhancing students' reading comprehension. Because, according to Cohen's (1988) criterion of the magnitude of effect sizes, such effect size of .11 is somewhat small in terms of educational significance.

With respect to an educationally non-positive effect of SSR on reading comprehension, a variety of plausible explanations could be provided. First of all, an impact of reading attitude improved by SSR on reading comprehension is not direct so that a positive reading attitude may not necessarily play a crucial role in enhancing reading comprehension. That is, attitude toward roding influcnces intention to read, which increases exposure to reading matcrials, which in turn improves reading comprehension. However, a positive attitude toward reading may not always increase a student's reading behavior (i.e., exposure to print). This is especially true when his or her reading behavior must compete with other options such as sports, computer games, taking out-of-school extra classes at the commercial cram schools, social communities, and watching TV. A positive intention to read may not be enough to cause a reading behavior to occur after school. Thus, gains in reading attitude are not likely to enhance a student's exposure to print or after-school reading, which plays a crucial role in enhancing vocabulary knowledge and background knowledge. Consequently, even significant changes in reading attitude may not directly produce significant changes in reading comprchension (Yoon, 2002a, 2000b).

The results from the moderator variables yield an answer to the second research question. The fact that students in the experiments of less-than-6-month duration of treatment $(\mathrm{ES}=.10$ ) did not gain significantly more reading comprehension scores than their peers in the experiments of more-than-6month duration of treatment (ES $=.09$ ) provides cvidence to support that the effectiveness of the reading activity at improving students' reading comprehension is not associated with duration of treatment. In other words, the activity equally enhances students' reading comprehension regardless of duration of treatment. Because a semester-treatment-duration may substantially long enough to provide opportunities for students to have a joyful reading experience as compared with one-year-duration of treatment in school context. However, students may not maintain this positive effect of the activity over a relatively short period time, for example, one month because the possibility that they have a pleasing reading experience may decrease as duration of treatment reduces.

In contrast, the heterogencity statistic for grade levels showed that effect sizes differ on 
students' grade levels. For the lower grade students, the average effect size was .20 , which corresponds to the 58th percentile, whereas for the higher-grade students, the mean effect size was .16 , which corresponds the 56th percentile. The results indicate that the reading comprehension score of the average individual in the SSR group exceeds the scores of $58 \%$ and $56 \%$ of individuals in the control group, respectively. Concerning Cohen's (1988) criterion of the magnitude of effect size, however, the effect size for both the lower students and the higher students is somewhat small. One of plausible explanations is that low-grade students benefit from the activity because high graders' reading attitude tends to decline gradually as more and more they participate in leisure options such as sports and social communities, which decreases their out-of-school reading time. In turn, it appositively influences exposure to print. Thus, later intervention in an effort to enhance reading comprehension may not have a significant impact on it. This result also supports the recommendation of earlier intervention in improving children's attitude toward reading and then fostering reading comprehension.

In sum, this meta-analysis provides the quantitative estimate of the relationship between SSR and reading comprehension, indicating that providing a fixed period of time for students to read matcrials of their own choosing either for pleasure or for information may not sufficiently facilitates their reading comprehension in terms of educational significance. To foster children's reading comprehension through the SSR activity, therefore, it should be combined with a variety of literacy activities such as writing, discussion, and talking that increase participation and interaction with their peers and teachers. Funthermore, as Demos (1986) pointed out, extending the SSR activity into the home environment may be a way of reinforcing attitude toward reading as well as of providing additional reading opportunities for children to promote reading comprehension. For lower-grade students, especially, an opportunity to read materials of their own choosing as a scheduled part of their school day should be provided because they bencfit from earlier intervention in improving their reading comprehension.

Admittedly, the current study has limitations. First, all eligible studies might not be exhausted. Second, by the very nature of a meta-analysis, qualitative research relevant to SSR was not included. Finally, due to a lack of theoretical background of multi-way interactions among moderator variables, more advanced analyses could not be conducted. Thus, the findings from this study should be carefully interpreted. 


\section{References}

Anderson, C.R., Wilson, P.T., \& Fielding, L.G.(1988). Growth in reading and how children spend their time outside of school. Reading Research Quarterly, 23, 285-303.

Anderson, R.C. \& Freebody, P.(1981). Vocabulary knowledge. In J.T. Guthrie (Ed.), Comprehension and teaching: Research reviews(pp. 77-117). Newark, DE: International Reading Association

Bandura, A.(1986). Social foundations of thought and action: A social cognitive theory. Englewood Cliffs, NJ: Prentice Hall.

*Box, L.(1984). A study of achievement and attitudes of high-achieving, average-achieving, and low-achieving third grade students involved in daily sustain silent reading. Unpublished doctoral dissertation, Mississippi State University, Mississippi.

Bransford, J.D., \& Johnson, M.K.(1972). Contextual prerequisites for understanding: Some investigations of comprehension and recall. Journal of Verbal Learning and Verbal Behavior, 11, 717-726.

Burley, J.(1980). Short-term, high-intensity reading practice methods for upward bound students: An appraisal. The Negro Educational Review, 31, 156-161.

Cecil, N.L.(1984). Impact of interest on the literal the literal comprehension of beginning readersa West Indian study. The Reading Teacher, 37, 750-753.

Cipielewski, J., \& Stanovich, K.E.(1992). Predicting growth in reading ability from children's exposure to print. Journal of Experimental Child psychology, 54, 74-89.

Cohen, J.(1988). Statistical power analysis for the behavior science (2nd ed.). Hillsdale, NJ: Erlbaum.

*Collins, C.(1980). Sustained silent reading periods: Effect on teacher's behavior and students' achievement. The Elementary School Journal, 81, 109-114.

*Davis, Z.T.(1988). A comparison of the effectiveness of sustained silent reading and directed reading activity on students'reading achievement. The High School Journal, 72, 46-48.

Deci, E.L., \&Ryan, R.M.(1985). The general causality orientations scale: Self-determination in personality. Journal of Research in Personality, 9, 109-134.

Demos, E.S.(1986). Parent, schools, and HSSR. Reading Horizons, 26, 262-265.

*Dully, M.(1989). The relation between sustained silent reading to reading achievement and attitude of the at-risk student. (ERIC Document Reproduction Service No. ED 312 631) 
Dymock, S.J.(2000). The effect of sustained silent reading on reading comprehension: A review of the research. Paper presented at the National Reading Conference, 50th annual meeting, Scottsdalc, AZ.

Elley, W.B.(1994). Voluntary reading activities. In W.B. Elley (Ed.), The IEA study of reading literacy: Achievement and instruction in thirty-two school systems (pp. 65-148). Tarrytown, NY: Author.

*Evans, H.M., \& Towner, J.C. (1975). Sustaincd Silent Reading: Docs it increase skills? The Reading Teacher, 29, 155-156.

Farrell, E.(1982). SSR as the core of a junior high reading program. Journal of Reading, 26, 48-51.

Fink, R.P.(1996). Successful dyslexics: A constructivist study of passionate interest reading. Journal of Adolescent \& Adult Literacy, 39, 268-280.

Gambrell, L.B.(1981). The clip sheet. The Reading Teacher, 34, 836-838.

Gotffried, A.E.(1990). Academic intrinsic motivation in elementary and junior high school students. Journal of Educational Psychology, 77, 631-645.

Harris, T.L., \& Hodges, R.E.(1995). The litcracy dictionary. Newark, DE: Intenational Reading Association.

Hedges, L.V., \& Olkin, I.(1985). Statistical methods for meta-analysis. Orland, FL: Academic Press.

Henry, T.(2001, December 4). Getting a read on US tecns. US Today, p. 7D.

*Higgins, K.J.(1981), Sustained Silent Reading in the fifth grade: the effects of Sustained Silent Reading on speed, comprehension, word study skills, and vocabulary. Unpublished doctoral dissertation, Brigham Young University, Provo.

Hunt, L.C.(1970). Updating the individual approach to reading: IPI of IRP? (ERIC Document Reproduction Service No. ED 044 244)

Langford, J.C., \& Allen, E.G.(1983). The effects of U.S.S.R. on students' attitudes and achievement. Reading Horizons, 23, 194-200.

Morrow, L.M.(1991). Promoting voluntary reading. In J. Flood, J.M. Jensen, D. Lapp \& J.R. Squire (Eds.), Handbook of research on teaching the English language arts (pp. 681-690). New York: Macmillan.

Nagy, N.M., Campenni, C.E., \& Shaw, J.N.(2000). A survey of sustained silent reading practices in seventh-grade classrooms. Reading Online [On-line]. 1-12. Available: www.readingonline.org/ articles/nagy/ssr.html. 
National Reading Panel.(2000). Teaching children to read: An evidence-based assessment of the scientific research literature on reading and its implication for reading instruction. Available [Online] http:/www.nichd.nih.gov/publications/nrp/report.htm.

${ }^{*}$ Reedy, J.D.(1994). Effects of a sustained silent reading program with literature response joumals on third graders' attitude reading achievement and writing. Unpublished doctoral dissertation, Baylor University, Waco.

Rchder, L.G.(1980). Rcading skill in a paperback classroom. Reading Horizons, 21, 16-21.

Rosenthal, R.(1979). The file draw problem and tolerance for null results. Psychological Bulletin, $86,638-641$.

Rosenthal, R.(1984). Meta-analytic procedures for social research. Beverly Hills, CA: SAGE.

Schiavone, J.P.(2000). Sustained silent rcading and reading workshop: The impactof accountability on seventh graders" reading comprehension and reading attitude. Unpublished doctoral dissertation, George Washington University, Washington, D.C.

Schiefele, U.(1991). Interest, learning, and motivation. Educational Psychologist, 26, 299-323.

${ }^{*}$ Schon, 1., Hopkins, K., \& Vojir, C.(1985). The effects of special reading time in Spanish on the reading abilitics and attitudes of Hispanic junior high school students. Journal of Psycholinguistic Research, 14, 57-65.

Schwarzer, R.(1996). Unpublished manuscript. Available [Online] www.yorku.ca/faculty/academics/schwarze/meta-e.htm.

Shannon, P.(1995). Texts, lics, \& vidcotape: Stories about life, litcracy, \& learning. Portsmouth, NH: Heinemann.

Stanovich, K.E.(1986). Matthew effects in reading: Some consequences of individual differences in the acquisition of literacy. Reading Research Quarterly, 21, 360-406.

*Summers, E.G., \& McClelland, J.V.(1982). A ficld-based evaluation of sustaincd silent reading (SSR) in intermediate grades. The Alberta Joumal of Educational Research, 28, 100-112.

Wheldall, K., \& Entwistle, J.(1988). Back in the USSR: The effect of teacher modeling of silent reading on pupils' reading behavior in the primary school classroom. Educational Psychology: An International Journal of Experimental Educational Psychology, 8, 51-66.

*Wilmot, M.P.(1975). An Investigation of the Effect upon the Reading Petformance and Attitude toward Reading of Elementary Grade Students, of Including in the Reading Program a Period of Sustained, Silent Reading. Unpublished doctoral dissertation, University of Colorado, Boulder.

Yoon, J.-C.(2002a). Three decades of sustained silent reading: A meta-analytic review of the 
effects of SSR on attitude toward reading. Reading Improvement, 39, 186-195.

Yoon, J.C.(2002b). Effectiveness of sustained silent reading on reading attitude and reading comprchension of fourth-grade Korcan students. Unpublished doctoral dissertation, The University of Georgia, Athens.

Zephaniah, D.(1988). A comparison of the effectiveness of sustainedsilent reading and directed reading activity on students' reading achievement. High School Journal, 72, 46-48.

- 논문접수 : 2003 년 10 월 8 일/ 수겅본 접수 : 2003 년 11 월 20일/ 개새 승인 : 2003 년 12 열 4 일 


\section{초록}

아침 읽기 활동 30 : 읽기 이해에 대한 메타 분석

윤 준 채

(한국교육과정평가원)

본 메타 분석의 목적은 읽기 이해에 대한 아침 읽기 할동의 전반적인 효과와 그것에 영 향을 주는 중재 변인을 탐색하는데 있다. 이를 위해, Hedges와 Olkin이 개발한 메타 분석 방법을 사용했다. 분석 결과에 의하면, 읽기 이해에 대한 평균 효과의 크기는 .11이었으며, 중재 변인 중에서는 학년만이 유의했다. 이것은 학습이나 여가를 위해 학생들에게 일정 시 간 동안 읽기 매체를 읽을 수 있는 기회를 제공해 주는 읽기 활동, 즉 아침 읽기 활동은 학 생들의 읽기 성장을 촉진시키는데 한계가 있음을 보여준다. 따라서 학생들의 읽기 이해를 발달시키기 위해서, 아침 읽기 활동은 쓰기, 토의하기 등과 같은 다른 읽기 활동과 함께 제 공되어야 하며, 제공 시기는 빠를수록 효과적이다.

주제어 : 아침 읽기 활동, 메타 분석, 읽기 이해 